\title{
Devonian greenhouse conditions drove epigenetic copper-cobalt mineralisation in hydrothermal dolomite in passive margin setting
}

\author{
NICOLAS J SAINTILAN ${ }^{1}$, COREY ARCHER ${ }^{1}$, COLIN \\ MADEN $^{1}$, ELIAS SAMANKASSOU ${ }^{2}$, STEFANO M. \\ BERNASCONI ${ }^{1}$ AND JORGE E. SPANGENBERG ${ }^{3}$ \\ ${ }^{1}$ ETH Zürich \\ ${ }^{2}$ University of Geneva \\ ${ }^{3}$ University of Lausanne \\ Presenting Author: nicolas.saintilan@erdw.ethz.ch
}

Three key parameters exert the first-order controls on the secular distribution of giant sediment-hosted sulphide deposits (SHSD) in geological time $e^{[1,2,3]}$ : (1) the stepwise and decisive oxygenation of Earth's atmosphere and hydrosphere ${ }^{[4,5]},(2)$ the resulting speciation of dissolved sulphur ${ }^{[6]}$, (3) the time-resolved, robust link between SHSD and the edges of thick cratonic lithosphere ${ }^{[3]}$. This framework grants the possibility to explore the influence of paleoclimates on the genesis of SHSD. Here, we show that copper-cobalt $(\mathrm{Cu}-\mathrm{Co})$ sulphide mineralisation hosted by large, offshore carbonate platform in passive margin setting is genetically linked to the climax of Devonian greenhouse conditions 400 to 382 million years ago (Ma). Copper sulphide mineralisation took place at $377 \pm 14 \mathrm{Ma}$ (bornite $-\mathrm{Cu}_{5} \mathrm{FeS}_{4}$, rhenium-osmium isochron age) at the time when greenhouse conditions favoured carbonate reef formation, algal blooms, and evaporative "brine factories", including at high latitudes. Large molybdenum (Mo) isotope variations $\left(\delta^{98 / 95} \mathrm{Mo}=+2.04\right.$ to $+5.49 \%$ o $)$ in sulphides record large-scale brine flow within the carbonate platform and the rifted continental margin. The latter located bimodal magmatic activity in an epicontinental basin neighbouring the carbonate reef. In this setting, high heat flow contributed to upward movement of hot and relatively reduced brines carrying copper and hydrogen sulphide $\left(\delta^{34} \mathrm{~S}=-3.6\right.$ to $1.8 \%$ VCDT) leached from mafic lithologies in newly formed oceanic crust. The exchange of Mo isotopes between the mineralising fluids and organic matter, and the intimate association between carrolite $\left(\mathrm{Cu}\left[\mathrm{Co}, \mathrm{Ni}_{2} \mathrm{~S}_{4}\right)\right.$, bornite and pyrobitumen supports the view that bio-assimilated cobalt, rhenium, and germanium were derived from the algal organic matter. Abundances of these strategic metals in sulphide mineralisation depends on the extent of fluid-rock interaction and alteration of organic compounds that resulted in an increase in partial pressure of $\mathrm{CO}_{2}$ during and after dolomitization of carbonaceous limestone.

[1] Leach et al. (2010) Economic Geology 105, 593-625

[2] Hitzman et al. (2010) Economic Geology 105, 627-639

[3] Hoggard et al. (2020) Nature Geoscience 13, 504-510

[4] Lyons et al. (2014) Nature 506, 307-315

[5] Wallace et al. (2017) Earth and Planetary Science Letters 466, $12-19$

[6] Canfield (2005) Annual Reviews in Earth and Planetary Sciences 33, 1-36 